\title{
Waste Minimization Using Lean Tools in a Selected Ready Made Garments Factory in Bangladesh
}

\author{
Muhammad Abdus Samad*, Md.Tanvir Hasan, Md. Umar Faruk \\ Department of Industrial \& Production Engineering, Shahjalal University of Science and Technology, Bangladesh
}

Copyright $\mathrm{C} 2019$ by authors, all rights reserved. Authors agree that this article remains permanently open access under the terms of the Creative Commons Attribution License 4.0 International License

\begin{abstract}
Ready Made Garments (RMG) industry plays an important role for the economic development of Bangladesh. This industry has promoted our country in the world through the motto 'Made in Bangladesh'. But this sector has got a number of formidable challenges for the sustainable future growth. The phase out of export quota system has made the trading environment severely competitive. Moreover, in today's fast fashion, customer wants to get products of low cost and short lead time. To sustain in this competitive market, there is no alternative to adopt lean philosophy in every sphere of apparel industry for the sustainable development. The concept of lean is to eliminate the wastes that don't add value for the products and to reduce the lead time. This study focused on the reduction of lead time by minimizing the wastes that are responsible for longer lead time by using lean tools. Data was collected using time study method. Some data were also collected from interviewing with management. Then the current state of the value stream mapping was drawn. Wastes were identified by using value stream mapping. Pareto analysis was used to rank the wastes which were playing significant role for long lead time. Then root cause analysis was used to identify causes behind the wastes. Lean tools like Kanban, Single Minute Exchange of Die and Total Productive Maintenance were used to minimize the wastes. Then the future state of the value stream mapping was drawn that depicted the improvement. Finally, this study suggested some recommendations for minimizing wastes and making their processes more efficient and leaner. This study extracts the common scenario of the garments sector of Bangladesh by depicting the existing pictures of the value stream. It is high time apparel industry of Bangladesh fully absorbed lean philosophy and walked through the path of continuous improvement.
\end{abstract}

Keywords Lead Time, Wastes, Lean Philosophy, Value Stream Mapping, Lean Tools

\section{Introduction}

In today's world of rapid flux, organizations change their focuses on speed. Customers, in today's competitive environment demand shorter lead time, low cost, high quality \& highly customize product. The customer is king of today market. Hence to compete effectively short lead times are essential to provide customer satisfaction. Lead time is the time elapse between placing of an order and the actually receipt of goods ordered. Most manufacturing firms spend $5 \%$ to $30 \%$ of total time actually adding value to the product. The rest of the time is waste. So, there is vast opportunity to reduce lead time [1].Value Stream Mapping (VSM) has appeared as the preferred way to implement lean, both inside factories and at the supply chain level linking those factories (Hines and Rich, 1997) [2]. VSM allows it's user to identify the steps which adds value and which doesn't add value by drawing current state. This is the static picture what's going on within a system. VSM helps its user to visualize the future state by improving the current state. [3]

Bangladesh is the fast growing economy powered by the readymade garments (RMG) industry which has promoted the country in the world through the motto 'Made in Bangladesh'. The sector accounts for $81 \%$ of total export earning of the country" [4]. Despite unquestionable success story, this sector has got a number of formidable challenges for the future growth. The competitor of the RMG sector has increased tremendously. Abolition of quota system and losing GSP have made the trading environment more competitive for Bangladesh. So, it is high time garments industry of Bangladesh adopted Lean philosophy and eliminated the wastes. Lean approach is used in identifying and eliminating waste from the process. Wastes can be categorized into seven types which are commonly referred to as "The 7 wastes of Lean" and these account for up to $95 \%$ of all costs in non-Lean manufacturing environments [5]. So, wastes should be eliminated to gain the advantages over the competitor. Moreover, 'most manufacturing firms spend $5 \%$ to $30 \%$ of total time actually adding value to the 
product. The rest of the time is waste [1]. So, there is a vast scope to reduce the lead time by eliminating wastes.

\subsection{Purposes of the Research}

- To observe the existing scenario where there is no use of lean tools and techniques.

- To identify wastes which are liable for long lead time.

- To reduce lead time.

- To identify the potential rooms of improvement.

\section{Literature Review}

Value Stream Mapping (VSM) is a method developed by Toyota. The method VSM is used to visually represent the current and future states in the process of planning lean. VSM represents the material and information flow of a process. VSM considered both value added and non-value added activities. Value- added activity is any action that increase the market form or function of the product or service. A non-value added activity is any action that does not add market form or function. [3]

Ohno identified seven types of waste [5], which were reported later by Womack et al. (1990) [6]:

1. Over production: this when operations continue after they should have ceased. Over production leads to increased inventory.
2. Waiting: this is sometimes referred to as queuing and occurs when an upstream activity has not delivered its output on time.

3. Transport: unnecessary motion or movement of materials, such as work-in-progress (WIP) being transported from one place to another. Transport should be minimized because it increased lead times and does not add value. Furthermore, damage can occur during transport.

4. Extra processing: extra operations such as rework, handling, or storage that occur because of defects, overproduction, or excess inventory.

5. Inventory: all inventory not needed directly to fulfill customer orders is waste. Inventory requires extra handling and space.

6. Motion: refers to the extra steps taken to accommodate inefficient layout, defects, reprocessing, overproduction, or excess inventory.

7. Defects: goods or services that do not conform to the specifications or customer expectations, thus causing dissatisfaction.

\section{Research Methodology}

This research is a case study type. Data were collected by using time study method. These data are field data. Some data were collected by interviewing with management. These data are collected data. Flow chart of research methodology is shown below figure-1: 


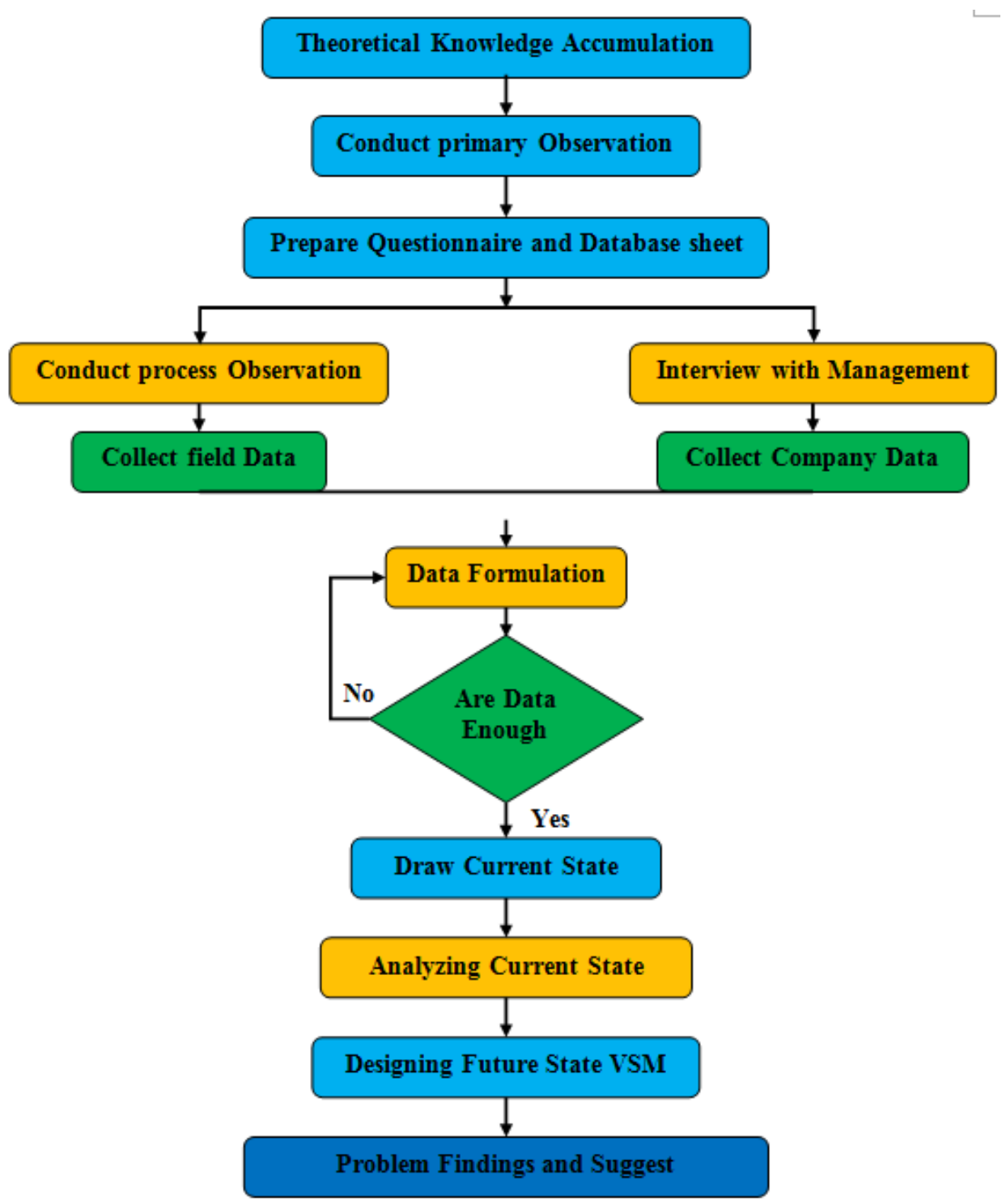

Figure 1. Flow chart of research methodology 


\section{Current State of Value Stream Map}

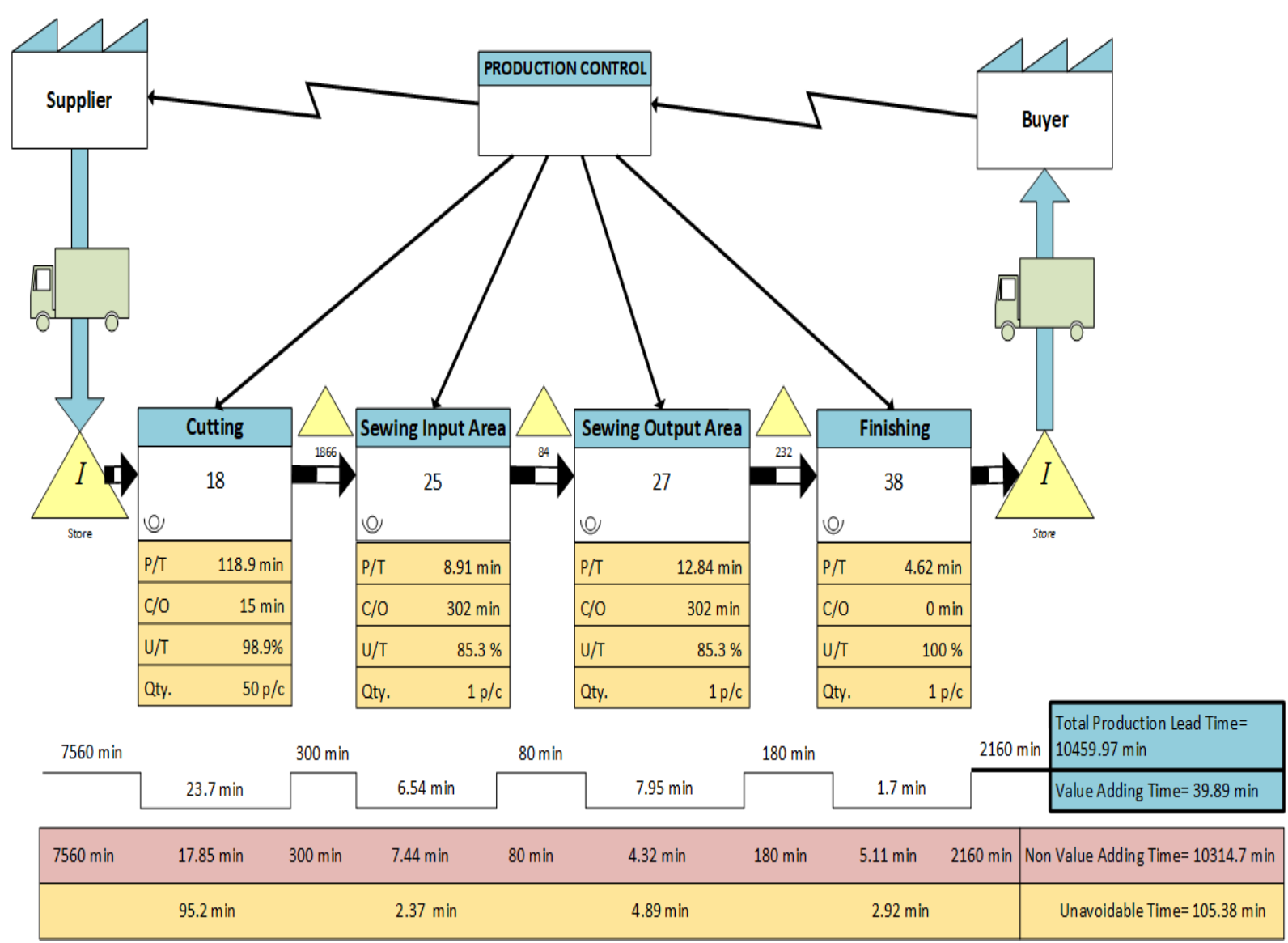

Figure 2. Current State of Value Stream Map

\subsection{Data Analysis}

This case study deals with the several type of wastes specifically excess inventory, waiting time. Change over time is also a non-value added task. Long changeover time reduces the machine uptime. So, changeover analysis is also important. Pareto analysis is conducted to single out which wastes play vital role to increase lead time. Then the reasons behind those wastes are identified. Then the reasons behind long changeover time is also analyzed so that machine uptime can be increased.

\subsubsection{Pareto Analysis of Wastes}

Table 1. Data calculation for wastes analysis

\begin{tabular}{|c|c|c|c|}
\hline Type of waste & Time(Min) & Percentage & Cumulative \\
\hline Excess Inventory & 7580 & $99.64 \%$ & $99.64 \%$ \\
\hline Waiting & 24.63 & $0.32 \%$ & $99.96 \%$ \\
\hline Excess Transportation & 2.97 & $0.04 \%$ & $100 \%$ \\
\hline
\end{tabular}




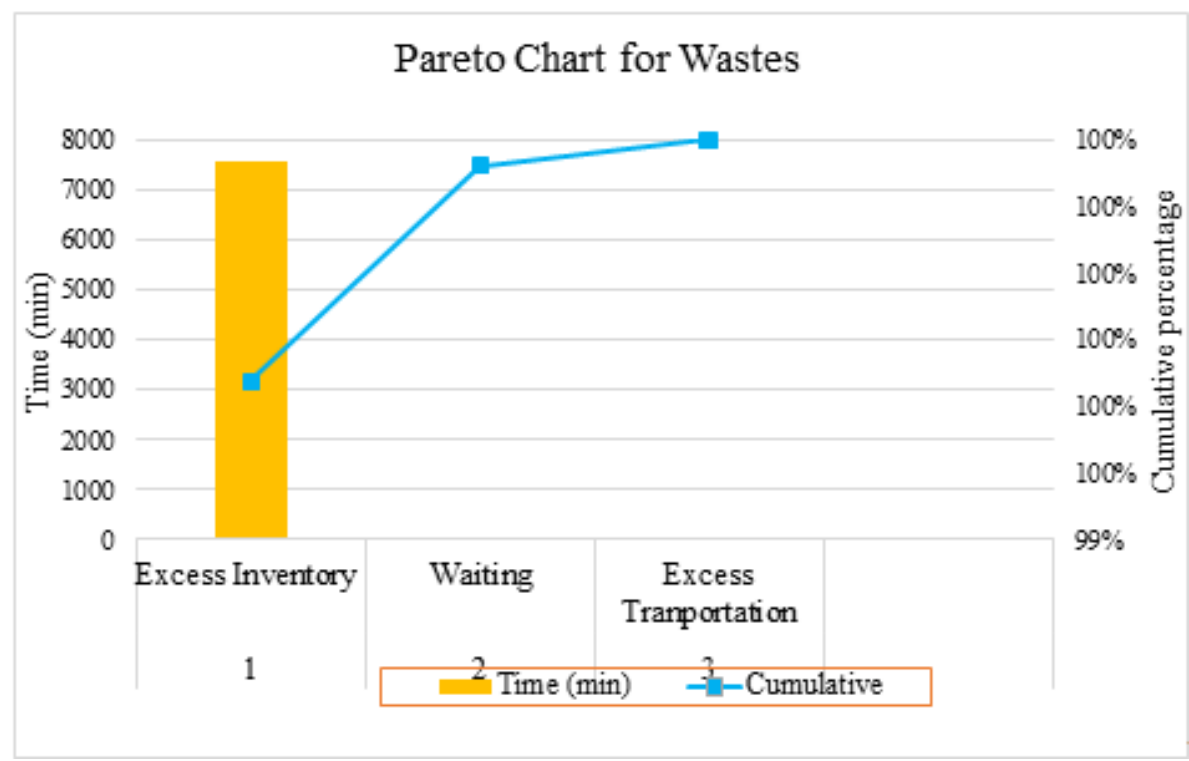

Figure 3. Pareto Chart for Wastes Analysis

\subsubsection{Analysis of Excess Inventory}

Among the three format of excess inventory which occupied what percentage of time for excess inventory is calculated and major problems responsible for excess inventory has been identified in this section.

Table 2. Data analysis of Excess inventory

\begin{tabular}{|c|c|c|c|c|c|}
\hline Waste type & $\begin{array}{c}\text { Format of Excess } \\
\text { inventory }\end{array}$ & $\begin{array}{c}\text { Time } \\
(\mathrm{min})\end{array}$ & $\begin{array}{c}\text { Total Time } \\
(\mathrm{min})\end{array}$ & Percentage & Problem behind \\
\hline \multirow{3}{*}{$\begin{array}{c}\text { Excess } \\
\text { inventory }\end{array}$} & $\begin{array}{c}\text { Raw material } \\
\text { Inventory }\end{array}$ & 4860 & & $64.12 \%$ & $\begin{array}{c}\text { Lack of supplier reliability } \\
\text { Information gap } \\
\text { Order less frequently }\end{array}$ \\
\cline { 2 - 3 } & WIP Inventory & 560 & \multirow{2}{*}{7580} & $7.39 \%$ & $\begin{array}{c}\text { Lack of co-ordination. } \\
\text { Information gap Layout } \\
\text { Lack of capacity. }\end{array}$ \\
\cline { 2 - 3 } & $\begin{array}{c}\text { Finished goods } \\
\text { Inventory }\end{array}$ & 2160 & & $28.49 \%$ & $\begin{array}{c}\text { Dependency on parent organization for shipment. } \\
\text { Transportation cost }\end{array}$ \\
\hline
\end{tabular}

\subsubsection{Analysis of Waiting Time}

From the Pareto analysis, it is shown that waiting time is the second largest waste. The table given below shows the waiting time in different departments.

Table 3. Root cause analysis of machine failure

\begin{tabular}{|c|c|c|c|}
\hline Problem Type & Observed frequency & Required Time (sec) & Root cause \\
\hline Skipped stitches & 6 & 92.76 & $\begin{array}{l}\text { Needle is incorrectly inserted. } \\
\text { Needle is not threaded properly. } \\
\text { Needle is not suitable for fabric. }\end{array}$ \\
\hline Over lock machine trip & 3 & 108.49 & $\begin{array}{l}\text { Thread is jammed in hook mechanism. } \\
\text { Machine has not been plugged in firmly. }\end{array}$ \\
\hline Jig-jag machine trip & 3 & 167.53 & $\begin{array}{l}\text { Thread is jammed in hook mechanism. } \\
\text { Machine has not been plugged in firmly. } \\
\text { Machine needs oil }\end{array}$ \\
\hline Needle break & 1 & 15.9 & $\begin{array}{l}\text { Needle is not inserted properly } \\
\text { Needle is bent }\end{array}$ \\
\hline Fabric not being fed smoothly & 1 & 9.87 & Presser foot has raised \\
\hline Seam is not sewn neatly & 2 & 49.62 & $\begin{array}{l}\text { Needle and loop thread tension are not correctly adjusted. } \\
\text { Needle is not suitable for fabric }\end{array}$ \\
\hline Needle thread cut & 3 & 11.89 & $\begin{array}{l}\text { Needle thread is not threaded properly. } \\
\text { Needle is incorrectly inserted }\end{array}$ \\
\hline Bobbin thread breaks & 2 & 13.83 & $\begin{array}{l}\text { Bobbin does not rotate smoothly. } \\
\text { Bobbin thread is not placed properly in bobbin holder. }\end{array}$ \\
\hline Demonstration & 4 & 50.46 & Unskilled operator \\
\hline
\end{tabular}




\subsubsection{Changeover Analysis}

A bar chart of identified elements with their consumed time is presented in the figure 4

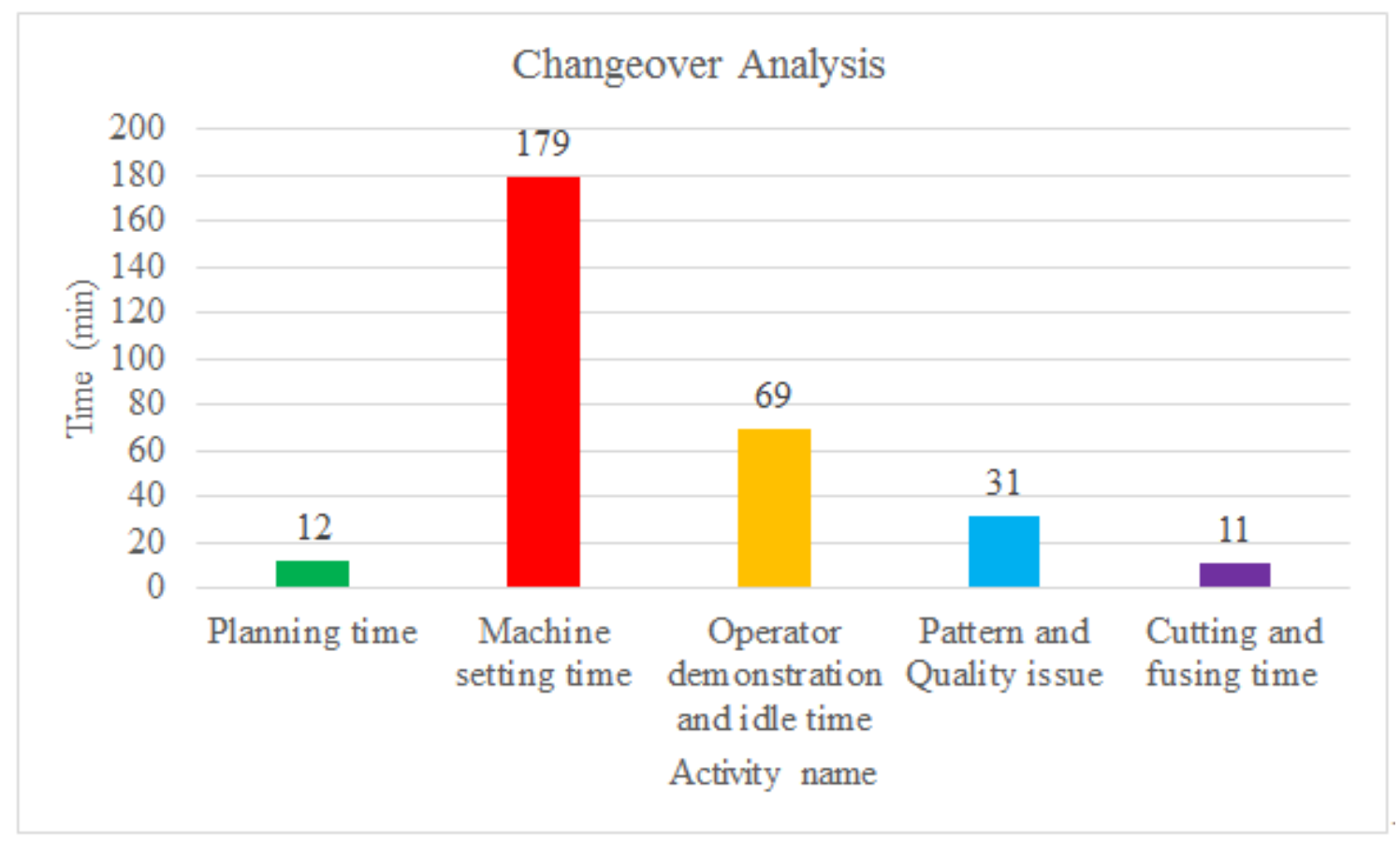

Figure 4. Changeover analysis

From the figure above, it is clear that the maximum amount of time lost during line setup is due to setting up of the machines according to the new design, time is also lost due to demonstration and re-demonstration of the operators, during this time, several operators are also observed to be sitting idle with no work on their stations at all. Another area of problem observed during the setup of this line is the unclear sewing and quality instructions made available to the supervisors and the operators by the quality team. This led to a lot of unnecessary rework that could have been avoided with proper planning.

\section{Improvement Strategy}

\subsection{Reduction of WIP Inventory Time}

From data analysis, it is found that, $7.39 \%$ of excess inventory time is occupied by WIP inventory time. It is observed that layout problem and information gap is responsible for this mostly.

\subsubsection{Reduction of Information Gap}

Root cause behind the problem is identified and strategy for the improvement is provided.

Table 5. Analysis of information gap

\begin{tabular}{|c|c|c|c|c|c|c|c|}
\hline $\begin{array}{l}\text { Waste } \\
\text { Type }\end{array}$ & $\begin{array}{c}\text { Problem } \\
\text { behind }\end{array}$ & $\begin{array}{l}\text { Root cause behind the } \\
\text { problem }\end{array}$ & \multicolumn{2}{|c|}{ Current State } & $\begin{array}{c}\text { Improvement } \\
\text { Strategy }\end{array}$ & \multicolumn{2}{|c|}{ Future State } \\
\hline \multirow{3}{*}{$\begin{array}{c}\text { WIP } \\
\text { inventory }\end{array}$} & \multirow{3}{*}{$\begin{array}{l}\text { Information } \\
\text { gap }\end{array}$} & \multirow{3}{*}{$\begin{array}{l}\text { Lack of effective } \\
\text { communication method. }\end{array}$} & Flow direction & $\begin{array}{l}\text { Time } \\
(\mathrm{min})\end{array}$ & \multirow{3}{*}{ Kanban } & $\begin{array}{c}\text { Flow } \\
\text { direction }\end{array}$ & $\begin{array}{l}\text { Time } \\
(\mathrm{min})\end{array}$ \\
\hline & & & $\begin{array}{l}\text { Cutting- } \\
\text { Sewing I/A }\end{array}$ & 300 & & $\begin{array}{l}\text { Cutting- } \\
\text { Sewing }\end{array}$ & 60 \\
\hline & & & $\begin{array}{l}\text { Sewing O/A- } \\
\text { Finishing }\end{array}$ & 180 & & $\begin{array}{l}\text { Sewing } \\
\text {-Finishing }\end{array}$ & 60 \\
\hline
\end{tabular}




\subsubsection{Layout}

\subsubsection{Current Layout of Sewing Line}

In Kimberly Fashions Ltd., the layout of the sewing line has been divided into two section named as input area and output area. This interrupts the continuous flow of the materials. Figure 5.shows the current layout of sewing line.

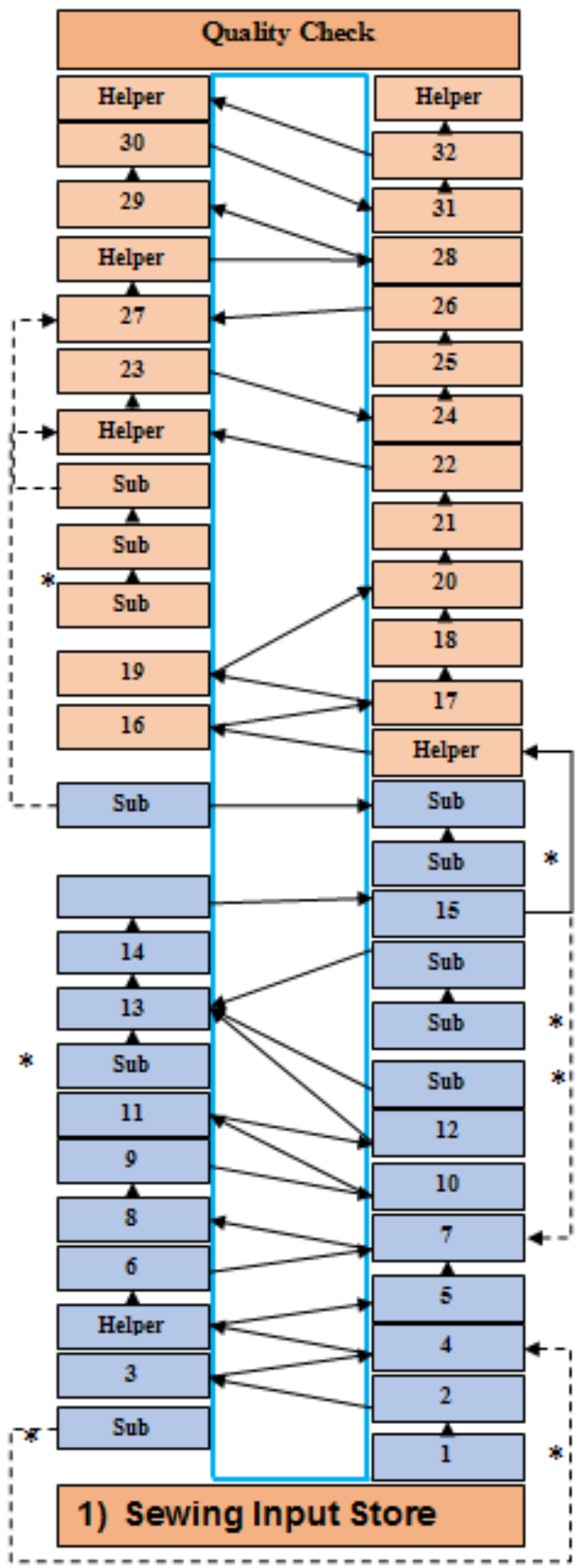

Figure 5. Current layout of Sewing line

\subsubsection{Modified Layout}

Division of the sewing line has to be vanished that will ensure the continuous flow of the material. Figure 6 shows the suggested modified layout of sewing line.

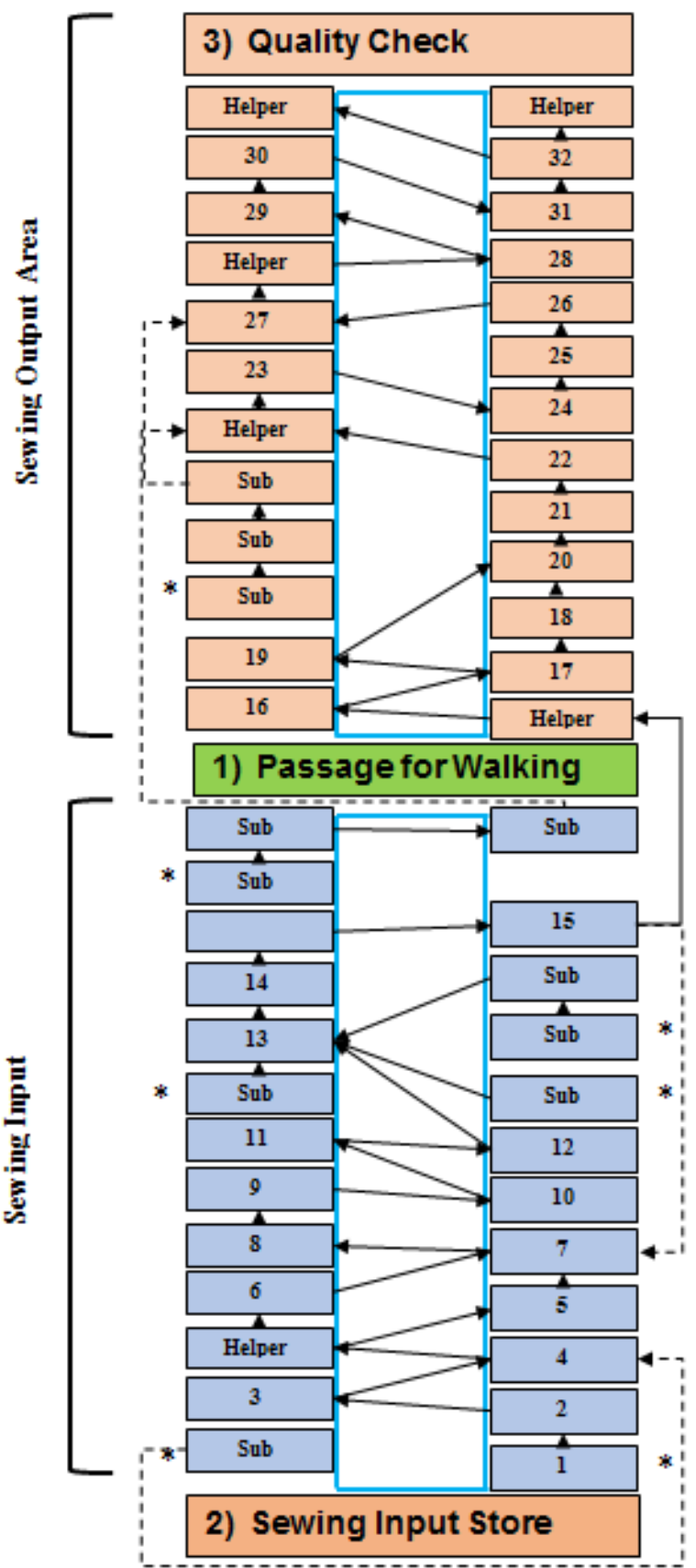

Figure 6. Modified layout of Sewing line 


\subsection{Reduction of Waiting Time}

From data analysis, it is found that waiting time exists in every department. In this section strategies to reduce waiting time is provided.

\subsubsection{Reduction of Waiting Time in Cutting}

By implementing TPM, machine breakdown time can be reduced to $35-45 \%$ [7]. So, average breakdown reduction $=$ $40 \%$. So, reduction of machine failure time is $=5.7 * 40 \%$ $\min =2.28 \mathrm{~min}$.

5.2.2. Reduction of Waiting Time in Sewing

Total machine failure time due to the lack of maintenance is $=464.67 \mathrm{sec}$. From the data of sewing line it is shown that Total Actual performance including 13\% PFD allowances is $=2334.12 \mathrm{sec}$. This significant of machine failure time can be reduced by using TPM. By implementing TPM, machine breakdown time can be reduced to $35-45 \%$ [7]. So, average breakdown reduction $=$ $40 \%$. So, machine breakdown time in sewing can be reduced $=464.67 * 40 \% \mathrm{sec}=185.89 \mathrm{sec}$.

\subsection{Strategies to Reduce Changeover Time}

SMED concept involves separation of machine set up elements into External and Internal elements. The goal is to make as many elements as possible into external so as to reduce the internal setup time. 


\subsection{Creating Future Value Stream Mapping}

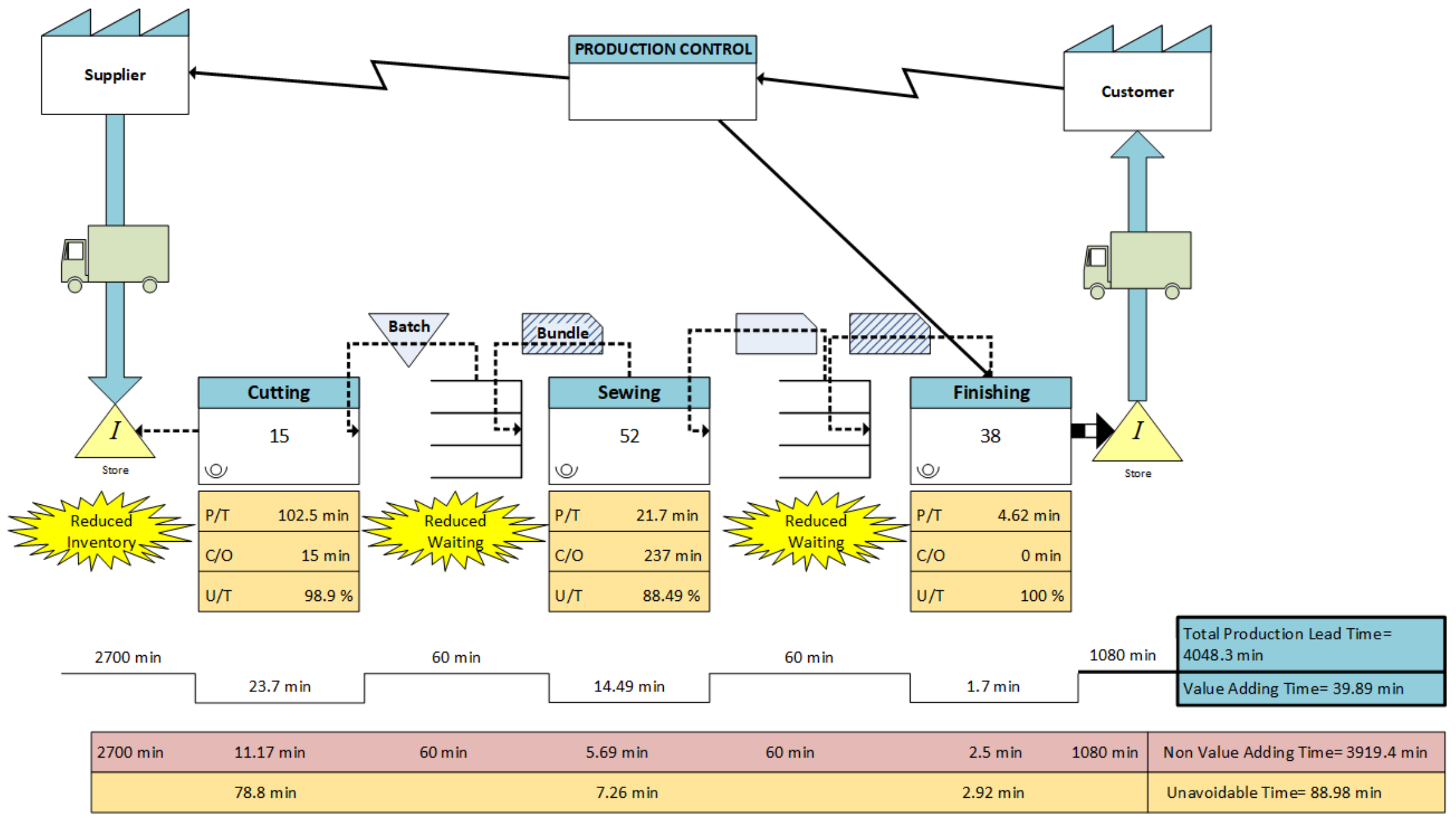

Figure 7. Future State Value Stream Map

\section{Result}

The comparison table between the current state value state map and the future state value stream is given below. 
Table 7. Results comparison between current state and future state

\begin{tabular}{|c|c|c|c|c|}
\hline Factor & Current State Map & \multicolumn{2}{|r|}{ Strategies followed } & Future State Map \\
\hline Excess Inventory & $7580 \mathrm{~min}$ & \multicolumn{2}{|r|}{ Kanban, Layout modification } & 120 \\
\hline Waiting Time & 24.65 & \multicolumn{2}{|r|}{ TPM, Increase capacity } & 15.94 \\
\hline Material flow system & Push & \multicolumn{2}{|r|}{ Kanban } & Pull \\
\hline Non-value added unavoidable time (cutting) & $95.2 \mathrm{~min}$ & \multicolumn{2}{|c|}{ Installed automatic fabric spreading machine } & $78.8 \mathrm{~min}$ \\
\hline Changeover Time & $302 \mathrm{~min}$ & \multicolumn{2}{|r|}{ SMED } & $237 \mathrm{~min}$ \\
\hline Total Non-value added Time & \multicolumn{2}{|c|}{$10314.7 \mathrm{~min}$} & \multicolumn{2}{|c|}{$3919.4 \mathrm{~min}$} \\
\hline Total Unavoidable Non-value added time & \multicolumn{2}{|c|}{$105.38 \mathrm{~min}$} & \multicolumn{2}{|c|}{88.98} \\
\hline Total Lead Time & \multicolumn{2}{|c|}{$10459.97 \mathrm{~min}$} & \multicolumn{2}{|c|}{$4048.3 \mathrm{~min}$} \\
\hline
\end{tabular}

\section{Recommendation}

For the improvement of the selected garments factory, below some recommendations are to be proposed:

- Value stream mapping should be applied to know the current state and to identify different types of waste.

- Traditional push system should be replaced with Kanban Super market Pull system to reduce waiting time and WIP.

- Layout needs to be changed to reduce unnecessary transportation time.

- Bottleneck point should be identified to get the maximum output from the production line.

- To minimize other wastes, other lean techniques should be applied such as zero defects, line balancing, 5S, Poka-Yoke, JIT etc.

- Some process it is very difficult to eliminate the waste at a time, in that case the continuous improvement or Kaizen should be implemented.

- Worker training and motivation session should be strongly activated.

\section{Research Limitation}

The objectives of this thesis were accomplished. However, there were some obstacles which caused some limitations in the thesis work. These are:

- Implementation of the change will incur cost. So, it was not possible to implement the changes in the company.

- In this study, only one style was considered. To avoid complexity other style was not considered in this study.

- Due to the lack of the cost related data, the cost analysis isn't possible to conduct.

\section{REFERENCES}

[1] Afzal H. Alad, Vivek A. Deshpande, 2014, a review of various tools and techniques for lead time reduction.
[2] Peter Hines Nick Rich, (1997),"The seven value stream mapping tools", International Journal of Operations \& Production Management, Vol. 17 Iss 1 pp. 46 - 64

[3] Bangladesh Garment Manufacturers and Exporters Association [BGMEA], retrieved fromhttp://www.bgmea.c om.bd/home/about/AboutGarmentsIndustry.

[4] James Chapados and AgnieszkaPerlinska, What is a Kanban, Retrieved fromhttps://www.scribd.com/document/4609924 3/kanban.

[5] Ohno, Taiichi (1988), Toyota Production System: Beyond Large-Scale Production, Productivity Press, ISBN 0-915299-14-3.

[6] Womack, J. P., Jones, D. T., \& Roos, D. (1990). The machine that changed the world: The story of lean production. New York: Rawson Associates.

[7] Brady Worldwide Inc, ISO-14001, Total productive maintenance, Retrieved fromhttps://www.bradyid.com/app lications/lean-visual-workplace/lean-visual-workplace-tpm 